\title{
The Professionalism of Indonesian Teachers in The Future
}

\author{
Iis Lisnawati \\ Siliwangi University, Indonesia \\ E-mail: is.lisnawati@yahoo.co.id
}

\begin{abstract}
Teachers are the most crucial factor in learning. Therefore, the process and success of learning as a determinant of the quality of education in the future were determined by the professionalism of teachers. The professionalism of Indonesian teachers in the future must be in line with the demands of their profession, namely (1) having teacher competence covering pedagogic competence, personality competence, social competence, and professional competence, (2) realizing Indonesian language learning in accordance with current curriculum , (3) implementing the paradigm of 21 st century learning that has nationalism, global perspective, and multi-literacy to produce graduates who have soft skill and hard skills that are superior and competitive so that they become qualified human resources.
\end{abstract}

Keywords: learning system, learning paradigm, teacher professionalism

\section{INTRODUCTION}

The teacher is a profession as stated in the Law of the Republic of Indonesia Number 14 Year 2005 on Teachers and Lecturers, Article 1, Paragraph 1 that teachers are professional educators with the main task of educating, teaching, guiding, directing, training, assessing, and evaluating learners early childhood education on formal education, basic education and secondary education. Law of the Republic of Indonesia Number 14 Year 2005 on Teachers and Lecturers, Article 4 stated the position of teachers as professionals serves to improve the dignity and role of teachers as a learning agent that serves to improve the quality of national education. In addition, the position of teachers as professionals aims to implement the national education system and realize the goals of national education. Namely the development of potential learners in order to become a human being who believes and cautious to God Almighty, noble, healthy, knowledgeable, capable, creative, independent, as well as being a democratic and responsible citizen (Law of the Republic of Indonesia Number 20 of 2003 on National Education System, Article 3 and Law of the Republic of Indonesia Number 14 Year 2005 on Teachers and Lecturers, Article 6).
The above description implies that teachers are the determinants of educational success (Ahmad, 2016: 3) suggest that teachers are a key factor in educational success. Therefore, the success of education in the future is also determined by the quality of teachers.

Future education is still part of the $21 \mathrm{st}$ Century education. 21st century is a century of knowledge, as information and technology evolve. One of the most prominent features in the $21 \mathrm{st}$ century is the increasingly interconnected world of science, so that the synergy of the more rapidly. In the context of the use of information and communication technology in the education sector, it has proven to be more narrow and melting factor "space and time" which has been the determinant aspect of speed and success of mastery (National Education Standards Agency, 2010). Thus, the professionalism of future teachers must also be a concern as it is necessary to prepare graduates who can compete to take advantage of opportunities and challenges in the future.

\section{Methodology}

The literature review is the method used in this study. In this case the authors review books, 
articles, other documents in the form proceedings, government policy documents, and so on related to the topic discussed. The study was conducted to obtain information relating to the topic so as to provide solutions in solving the problems encountered. According to Creswell (2012) study literature is written summary of articles, books, and other documents that describes the past and current state of knowledge about a topic, organizes the literature into topics and documents a need for proposed study.

\section{RESULTS AND DISCUSSION}

\section{A. Teacher and Learning System}

Learning is a system. That is, the success of learning depends on the components of the learning system. Learning components include teachers, objectives must be formulated appropriately.

Learning material is the core of learning (Sanjaya, 2011: 60) because the learning material is a medium to achieve the purpose of teaching (Fathurrohman and Sutikno, 2009: 12). Learning materials that are not relevant to the learning objectives may lead to a predetermined objective not achieved. Thus, the material can be a determinant of learning achievement.

Fathurrohman and Sutikno (2011: 24) argue that the role of learning media will not be seen if its use is not in line with the essence of teaching objectives that have been formulated. Therefore, the purpose of teaching should be the base of reference for using the media. When ignored, the media is no longer a teaching tool, but as an obstacle in achieving goals effectively and efficiently. Thus, the failure of learning can be caused by the use of inappropriate media learning.

Strategy is a component that also has a very decisive function. Successful achievement of goals is largely determined by this component. However complete and clear the other components, without being implemented through the right strategy, then those components will have no meaning in the process of achieving the goal (Sanjaya, 2011: 60), Detailed Dick, Carey, and Carey (2009: 167-179) states that strategies include (1) delivery systems (relevant to the general methodology of learning); (2) sequencing and grouping of learning materials; (3) learning components of instructional strategies that include (a) pre-learning activities, (b) presentation of information, (c) student participation, (d) testing, and follow-up; and (4) grouping of students. Thus, any learning strategy is one of the critical success factors of learning.

According to Sanjaya (2011: 32) Evaluation plays an important role in learning because through the evaluation of teachers can determine whether the students who taught already have the competencies that have been set so they deserve new learning learners, learning objectives, learning materials, learning methods, instructional media, learning evaluations, administrative factors, and other facility factors.

With regard to the teacher, Sanjaya (2011: 6] argued that "in the teacher-learning process plays a very important role. Teachers are a very decisive component in the implementation of a learning ". In other words, the teacher is the determinant of the success of a lesson.

Learning objectives are an important component of learning. As Sanjaya suggests (2011: 64) that clear goals can assist teachers in determining learning materials, methods, or strategies, tools, media, and learning resources, as well as in defining and designing evaluation tools to see student success. Therefore, in order for learning to succecd, the

program is given; or even otherwise students have not reached the minimum standard so they need to be given remedial program. This statement implies that evaluation should always be relevant to the intended learning objectives. However, according to Sanjaya (2011: 32) the weakness that often occurs in connection with the implementation of the evaluation so far is the teacher in determining the success of students is limited to the results of the test in writing consequently the target of learning is limited to the ability of students to fill the usual problems out in the test. Thus, learning evaluation can be a cause of learning disadvantage because measuring should not be measured.

From the components of learning earlier, teachers are the most decisive factor of success of learning because teachers who determine the other learning components. As proposed by Iskandarwassid and Sunendar (2008: 159) that teachers as teaching planners instruct the duty of planning learning activities such as formulating goals, selecting materials, choosing methods, establishing evaluation, and so on. Also put forward Sanjaya (2011: 63) that in the learning process teachers play a very important role. Teachers are a very decisive component in the implementation of a learning. Thus, the success of learning is determined by the teacher. In this connection Sardjoko (2016), Sobri (2016) suggests that the quality of education is determined by the quality of teachers.

\section{B. Teachers in Educational Paradigm}

As a determinant of the success of learning, teachers must have certain competencies so that learning objectives can be achieved well. According to the Law of the Republic of Indonesia Number 14 Year 2005 regarding Teachers and Lecturers Chapter IV Article 10 paragraph 1 teacher competence includes pedagogic competence, personality competence, social competence, and professional competence. 
Pedagogic competence includes

1) Mastering the characteristics of learners from the physical, moral, social, cultural, emotional, and intellectual aspects.

2) Mastering learning theories and principles of educational learning.

3) Develop a curriculum related to the subject/field of development that is experienced.

4) Utilizing information, technology and communication for the benefit of learning.

5) Facilitate the development of the potential of learners to actualize various potentials.

6) Communicate effectively, empathically, and courteously with learners.

7) Conducting assessment and evaluation of learning process and outcomes.

8) Utilizing assessment and evaluation results for learning purposes.

9) Utilizing assessment and evaluation results for learning purposes.

10) Conduct a reflective action to improve the quality of learning.

\section{Personality competence includes}

1) Act in accordance with the norms of religion, law, social, and national culture of Indonesia

2) Showing the self as an honest person, noble character, and role model for the students and the community.

3) Showing yourself as a steady, stable, mature, wise, and authoritative person

4) Demonstrates work ethic, high responsibility, pridein being a teacher, and self-esteem.

5) Uphold the code of professional profession.

Social competence includes

1) Be inclusive, objective, and non-discriminatory because of gender, religion, race, physical condition, family background, and socioeconomic status.

2) Communicate effectively, empathically, and courteously with fellow educators, education personnel, parents, and the community.

3) Adopt on duty throughout the territory of the Republic of Indonesia which has a sociocultural diversity.

4) Communicate with the professional community itself and other professions orally and in writing or other forms.

Professional competence includes
1) Mastering the materials, structures, concepts, and scientific mindset that support the subjects which istaught

2) Mastering the competency standard and basic competence of the subject/field of development which istaught

3) Develop creative learning materials.

4) Develop professionalism in a sustainable manner by taking reflective action.

5) Utilizing information and communication technology to communicate and develop themselves.

The curriculum is one that must be mastered by teachers so that the professionalism of teachers can be realized. The current curriculum is Curriculum 2013. Curriculum 2013 puts Indonesian as the carrier and the advocate of science. It is not only related to the language but also the subjects students learn. This shows that the Indonesian lesson is very important. Therefore, Indonesian lessons should be in front of all other subjects.

The above is of course a consequence to the professionalism of Indonesian teachers. Indonesian teachers must be able to teach students well so that students become active users of Indonesian language both related to productive skills. In addition, the language used communicatively so that the role of Indonesian language as a science advocate can be realized when learners take education. Similarly, when students are in the social environment or after students graduate and socialize in the world of work, the Indonesian language used must be communicative. Thus, if the learners do not master certain subjects should be ensured that what he did not master is the substance of the subject, not because of the weakness of mastery of the language used. Similarly, when he was in the social environment or in the world of work, disability in the social environment or in the world of work is not caused by the mastery of the language.

The 2013 curriculum is a text-based curriculum. According to Biber \& Conrad (The Minister of Education and Culture, 2016) there are several principles behind the text as the focus of the study, namely (1) texts formed due to the demands of social activities; (2) the text has a social purpose; (3) the text form is the result of the convention; (4) language (grammar) a text is functional according to social objectives; and (5) the language of the text, such as vocabulary, grammar, or other characteristics should not be taught apart from the consideration of its text structure.

Various texts with its own characteristics of course require teachers to master all types of texts that must be taught as well as synergize with the role of the Indonesian language as a carrier, defender, and developer of science that requires students to do various thinking processes, both critical thinking, 
creative, or thinking to solve the problem by providing text content so that learning is not theoretical, but practical and functional.

According to Abidin (2015: 21) if learning is theoretical, the knowledge contained in the text will not be used as a means of thinking and writing activities as the expression of meaning will be uprooted by itself. Thus, language as a carrier and a defender of science will not be perceived by students during the learning process. Therefore, learning should also be oriented on literacy and multi-literacy so that learning is not a genre, but rather emphasizes reading deep comprehension, writing to express meaning, and speaking accountably. This is in line with the competencies developed in Indonesian language learning (The Minister of Education and Culture, 2016), which is developing the ability of learners in listening, reading, viewing, speaking, and writing. To achieve these competencies learners engage in language and literature activities through oral and written, print and electronic activities, threedimensional pages, and other visual images.

With regard to literacy, Directorate General of Primary and Secondary Education (2016: 8) explained that literacy is more than reading and writing, but includes thinking skills using printed, visual, digital, and auditory sources of knowledge. In this $21 \mathrm{st}$ century, this ability is referred to as information literacy.

Literacy of information by Clay and Ferguson (2016: 8) developed by the government through the School Literacy Movement (GLS) has six components: early literacy, basic literacy, library literacy, media literacy, technological literacy, and visual literacy, the teacher must be able to grow and develop student literacy in accordance with the level of literacy that must be mastered even more ..

The 2013 curriculum is implemented through the teacher's learning process. The learning process demanded by the Curriculum 2013 according to the Regulation of the Minister of Education and Culture No. 22 of 2016 is an interactive, inspirational, fun, challenging, motivational learning process to actively participate in, and provide sufficient space for the initiative, creativity, and independence according to talent, interests, and physical and psychological development of learners. For that every educational unit to do lesson planning, implementation of learning process and assessment of learning process to improve efficiency and effectiveness of competency achievement graduates.

According to the Pacific Policy Research Center (2010) key elements for fostering 21st century learning include (1) core subjects and themes (include traditional core subjects while emphasizing civic literacy, global awareness, financial literacy, health literacy, and environmental literacy, ), (2) critical learning and innovation skills (3) life and career skills (leadership and responsibility, productivity and accountability, social and crosscultural skills, (4) ) information, media, and technology skills (5) implementation of learning: (a) focus on real-world problems and processes (media literacy, information literacy, technological literacy, game-based learning, support systems: learning environments and professional development), (b) support inquiry-based learning experiences, (c) provide opportunities for collaborative project approaches to learning, (d) and focus on teach ing students how to learn (above "what" to learn), (6) assessment.

Learning is done essentially is to achieve the goals of national education. 21st National Education aims to realize the ideals of the nation, the people of Indonesia a prosperous and happy nation, with a respectable position and equal with other nations in the global world, through the formation of a society consisting of qualified human resources, namely selfreliant, and capable of realizing the aspirations of its people to produce productive, creative, innovative, and effective Indonesian people through strengthening attitudes (knowing why), knowing skills, and knowledge (know what) (National Education Standards Agency and BSNP, 2010).

The goal is of course based on the need for human resources in this century. The 21 st century is marked by (1) the amount of information available anywhere and accessible at any time, (2) faster computing (3) automation that replaces routine work and (4) communications that can be done from anywhere to (Research and Development Agency The Minister of Education and Culture. 2013). Therefore, the competencies and/or expertise that must be possessed by the 21 st. 21 st human resources in the "21st Century Partnership Learning Framework" (National Education Standards Agency, 2010) are (a) Critical-Thinking and Problem-Solving Skills - able to think critically, laterally, and systemically, especially in the context of problemsolving; (b) Communication and Collaboration Skills - able to communicate and collaborate effectively with various parties; (c) Creativity and Innovation Skills - able to develop the creativity it has to produce innovative breakthroughs; (d) Information and Communications Technology Literacy - able to utilize information and communication technology to improve daily performance and activities; (e) Contextual Learning Skills - able to undergo contextual independent learning activities as part of personal development; (f) Information and Media Literacy Skills - able to understand and use various communication media to convey ideas and carry out collaborative activities and interaction with various parties (National Education Standards Agency, 2010).

The behaviors human beings need in the twentieth century are as follows: (a) Leadership - the attitude and ability to be a leader and take the lead in 
initiating in order to produce breakthroughs; (b) Personal Responsibility - attitude is responsible for all acts committed as an independent individual; (c) Ethics- appreciates and upholds the conduct of ethics in the conduct of social life together; (d) People Skills - possesses a number of basic skills necessary to perform functions as individual and social beings; (e) Adaptability - able to adapt and adopt with the various changes that occur in line with the dynamics of life; (f) Self-Direction- has a clear direction and principle in its effort to achieve the ideal of an individual; (g) Accountability - conditions in which an individual has clear grounds and ground in every step and action taken; (h) Social Responsibility - has a responsibility to the surrounding environment and community; and (i) Personal Productivity - able to improve the quality of humanity through various activities and work done everyday (National Education Standards Agency 2010).

Binkley, et al. (2012: 18-19) suggests there are 10 skills that must be possessed by the $21 \mathrm{st}$ century human resources are grouped into 4 groups, namely (1) ways of thinking (think creative and innovative, critical thinking, thinking metacognition, (2) how to work (communicate and collaborating), (3) living (employment, career and career, as well as individual and social responsibilities), and (4) tools for work (information literacy, ICT literacy).

Konaspi VII held in 2012 in Yogyakarta that has produced the Yogyakarta Declaration stipulates that the 2045 gold-man of Indonesia is a Pancasilaspirited human being, who possesses global and futuristic skills, which can utilize science and technology based on cultural values and nationalism, as well as giving benefit to mankind (Konaspi VIII Jakarta, 2016).

Characteristics of Indonesian human resources that have been described and the characteristics of learning desired by the 21 stcentury, requires teachers to change the paradigm in designing, implementing and evaluating learning because learning is no longer teacher-centered but student-centered. Skill built not only hard skills but also soft skills. Pacific Policy Research Center (2010) states there has been a shift over the last century from manufacturing to emphasizing information and knowledge services.

The above opinion implies that teachers should not only have the competencies that have been established, but also must have the ability multi-literacy, insightful nationality, and global perspective. Thus, the professionalism of Indonesian teachers in the future should be improved, developed quality through characteristic indicators that must be owned. Both competency literacy, rational insight, and global insight are embodied in planning, implementing and evaluating learning.

With the professionalism of teachers as described, learning as education operationalization can form competitive graduates and become a superior and qualified human resource.

\section{CONCLUSION}

Teachers are the determinants of the success of learning because the components that exist in the learning system majority determined by the teacher. Professional teachers in the Indonesian language learning system in the future are teachers who are multi-competent, multi-literacy, national-minded, and globally minded to produce competitive graduates.

\section{REFERENCES}

Abidin, Yunus. 2015. Pembelajaran Multiliterasi. Bandung: PT Refika Aditama.

Ahmad, Intan. 2016. Arah \& Kebijakan Kementerian Riset, Teknologi, dan Pendidikan Tinggi: Kurikulum dan Sistem Pembelajaran LPTK. Konvensi Nasional Pendidikan (KONASPI) ke-VIII, ALPTKNI.

Research and Development Agency The Minister of Education and Culture. 2013. Kurikulum 2013: Pergeseran Paradigma Belajar Abad 21. [Online]. Available: http://litbang.kemdikbud.go.id/index.php/in dex-berita-kurikulum/243-kurikulum-2013pergeseran-paradigma-belajar-abad-21

Binkley, et al. (2012). "Defining Twenty-First Century Skills“. Assessment and Teaching of 21 st Century Skills. New York: Springer Science.

Creswell, J.W. Educational Research: Planning, Conducting, and Evaluating Quantitative and Qualitative Research. Boston: Pearson Education.

Dick, W., Carey, J.O. \& Carey, L. (2009). The Systematic Design of Instruction. Third Edition. USA: Harper Collins Publisher.

Directorate General of Primary and Secondary Educaetion 2016. Desain Induk Gerakan Literasi Sekolah. Jakrta: Dirjen Dikdasmen

Fathurrohman, P \& Sutikno, M.S. (2009). Strategi Belajar Mengajar: melalui Penanaman Konsep Umum dan Konsep Islami.Bandung: PT Refika Aditama.

Iskandarwassid \& Sunendar, D. (2008). Strategi Pembelajaran Bahasa. Bandung: Program Pascasarjana UPI dan PT Remaja Rosdakarya.

National Education Standards Agency, 2010 . Paradigma Pendidikan Nasional Abad 21.

The Minister of Education and Culture. 2016. Silabus Mata Pelajaran Sekolah Menengah Atas/Madrasah Aliyah. Jakarta:

Pacific Policy Research Center. 2010. Century Skills for Students and Teachers. [Online]. Available: www.ksbe.edu 
Regulation of the Minister of Education and Culture Number 22 Year 2016 on Standard Process of Primary and Secondary Education.

Sanjaya, W. (2011). Strategi Pembelajaran Berorientasi Standar Proses. Jakarta: Kencana Prenada Media Group.

Law of the Republic of Indonesia Number 20 Year 2003 on National Education System

Law of the Republic of Indonesia Number 14 Year 2005 on Teachers and Lecturers

Sardjoko, Subandi. (2016) Peningkatan Kualitas

Pendidikan Profesi Guru melalui

Revitalisasi LPTK. Konvensi Nasional Pendidikan (KONASPI) ke-VIII, ALPTKNI.

Sobri, Ahmad Yusuf. 2016. "Model-Model Pengembangan Profesionalisme Guru". Arah KebijakanPendidikan Guru di Indonesia (Prosiding). Konvensi Nasional Pendidikan (KONASPI) ke-VIII, ALPTKNI. 